\title{
Incentives to Promote Financial Performance of the Organization; Case Study of Companies Accepted in Tehran Stock Exchange
}

\author{
MOHAMMAD POSTI \\ Department of business management, Islamic Azad University-zanjan Branch, zanjan, Iran.
}

YADOLAH RAJAYEE

Department of economic, Islamic Azad University-zanjan Branch, zanjan, Iran.

\section{NABI ALAH MOHAMMADI}

Department of government management, Islamic Azad University-zanjan Branch, zanjan, Iran.

\section{KAMRAN YEGANEGI}

Department of Industrial Engineering, Islamic Azad University, Zanjan Branch , Zanjan, Iran. Email: yeganegi@iauz.ac.ir

\begin{abstract}
Managers in today's competitive world are facing a period that requires them to deploy a new economic framework in their companies; therefore, it is imperative to find the drivers that can be used to increase the firm's performance with a fairly reasonable confidence. Therefore, in this research, identifying the motivators promoting financial performance of the organization among the companies accepted in Tehran Stock Exchange has been discussed. Financial performance measurement indicators are also considered as the Tobin's $Q$ ratio and net profit growth. The present research is an applied research that is descriptivecorrelation based on the method. The statistical population of this research is composed of companies accepted in Tehran Stock Exchange between 2009 and 2015. The statistical sample is also used to determine the appropriate criteria and systematic elimination method, including 85 companies. The main tools for collecting data in this study were using financial statements and using the new generation software. The data were analyzed using EVIEWS software. The econometric method is also based on the data nature, which is a combination of annual and cross-sectional data, a data panel model. The results of data analysis showed that the percentage of ownership of institutional investors, ownership concentration, company assets and board diversity influenced the growth of net profit of companies accepted in Tehran Stock Exchange, which has a more negative effect on the board's diversity. Also, the results showed that the concentration of ownership, liquidity, company assets and the proportion of non-executive members of the board of directors had a significant effect on the ratio of the companies' quotes in the Tehran Stock Exchange. The effect of the liquidity on this financial ratio was negative. The results of this study support all three theories of representation, resources and stakeholders.
\end{abstract}

Keywords: Financial Performance, Ownership Concentration, Tobin's Q Ratio, Institutional Investors, Net Profit Growth, Diversity of Board of Directors. 


\section{Introduction}

Performance evaluation has always been considered as an important issue with the concept of representing meaning and concept. According to this theory, managers receive their rewards in accordance with their performance. As a result, shareholders can be sure that if managers give them the necessary incentives and control, they will make optimal decisions to maximize the wealth. Therefore, considering the importance of the issue in this study, we examine the stimuli enhancing the financial performance of the organization among the companies listed in Tehran Stock Exchange.

One of the most important goals of organizations operating in competitive environments is to gain competitive advantage. Today, organizations tend to achieve competitive advantage using the desired quality. Therefore, performance evaluation and quality improvement are essential. The evaluation of the organization's performance is one of the topics that managers and researchers have paid much attention to, and so far several publications and articles have been published in this regard. Performance appraisal is an effective means and means of human resource management that through proper actions of this tool, not only the objectives and missions of the organization will be realized with the desired performance, but also the interests of employees and society. The growth of organization and the excellence of its employees depends on the existence of an effective evaluation system and the application of its results (Mousavi et al., 2013).

The company's function is dependent on several factors. Many of the research that looked at the company's performance showed that organizations committed to strategic management had a better performance than other organizations. Achieving an appropriate communication loop between the organization's environment and its structure, its processes and processes has a positive effect on its performance (Arabi and Chavoshi, 2010). Andrews et al. (2006) argue that the multidimensional nature of organizational performance is due to the fact that organizations are expected to pursue a range of goals that may conflict with some of them. Therefore, organizations must focus on multiple dimensions of performance.

Some researchers believe that the sources of the company determine the superior performance and success of the market, while others see higher performance as a function of the capabilities and specific capabilities of the company (Suck et al., 2013). According to resource-based view, the superior performance of companies can be derived from their unique resources, resource integrity, or ability to respond to the environment. According to this view, differences in the performance of companies are due to the fact that successful organizations have physical, human and organizational resources that their competitors lack these resources. One of the important features of human resources that has high potential for creating competitive advantage is their ability to innovate and present new ideas. In particular, innovation enables the company to produce distinct, irresistible, scarce and valuable products, and thus leads to higher financial performance among companies (Sinai et al., 2011).

\section{Study Literature}

Ambo and AJA, in 2017, conducted a study titled "Enhancement Drivers for Corporate Performance." Research findings show that resource theory and representation can well explain the desired performance, as there is a positive relationship between board power and liquidity with performance. However, the influence of stakeholders on the board has a negative relationship with the performance of public corporations. Also, the high level of government intervention in setting tariffs leads to a weakening of performance. Based on the results, this paper concludes that the performance of public corporations is supported by a large number of organizational issues in the form of various theories, including representation, public policies, stakeholders and resources. The study suggests that the structure of stateowned companies should focus on four main areas: representation, stakeholders, resources, stakeholder engagement. From the point of view of the appointment of the board of directors, it must first be based on 
merit and then select the stakeholder as a subset. Available resources should be limited to policy issues through a legal and legal framework, with objective requirements and engagement with political leadership. Narwal and Patnja (2016) conducted a study on the effects of specific bank factors and specific factors governing bank governance on the productivity and profitability of banks. In this study, the indicators of profitability, size of organization, diversity, market share and extension as special variables of the bank and the size of the board of directors, the number of meetings of the board, the number of meetings of the audit committee and the fees paid to the members of the board of directors as special variables Governance was considered bank. The results of this study showed that there is a significant relationship between bank specific variables and productivity and profitability of the bank, but this relationship is among the specific variables of bank governance and poor productivity and profitability. The two variables of the board's board and board of directors are interpretations of the utility of state-owned banks, and the only conflict or dichotomy is the role that illustrates the profitability of private banks.

Tian et al. (2016) conducted a study on the creation of liquidity, regulatory capital and profitability of companies. The results of this study showed that regulatory capital and the creation of liquidity have positive effects on each other. Nevertheless, this relationship is largely occurring in small companies outside of the financial crisis. On the other hand, based on the results, companies with the ability to create higher liquidity and less risky tendencies are less profitable. Finally, the relationship between regulatory capital and company performance is not linear and depends on the level of capital accumulation. Regulatory capital also has a negative relationship with profitability for companies with high capital accumulation, but for companies with low capital accumulation this is a positive relationship.

Lee and Isa (2015) conducted a study on the remuneration of members of the board of directors, institutional governance and organizational performance of Malaysian companies. The results of this study showed that there is a positive and significant relationship between the amount of remuneration received by members of the board of directors and the performance of the companies. In addition, the results showed that this salary has a positive relationship with the percentage of independent board members and has a negative relationship with the size of the board. However, no significant relationship was found between the received remuneration and the duality of the members' responsibilities and the percentage of shareholding of the members.

Lee et al. (2014) conducted a study on the relationship between income diversification and the performance of companies in terms of the role of financial and liquidity reform. The purpose of this study was to examine the effect of diversification of corporate earnings through extensive financial reform, including credit control, control over received loans, market entry barriers, supervision, privatization and financial account constraints. This study was based on financial years 1995-2009, consisting of 2372 companies from 29 Asian countries. Based on the results obtained from this study, the diversification of portfolios has a positive impact on corporate performance. Particularly, structural and financial reforms to diversify corporate earnings can exacerbate the impact of income diversification on financial performance.

In 2014, Yashang and Luhani examined the relationship between competitive strategy, rewards for executives and company performance in the years 2000-2005 in 515 companies admitted to the stock exchange. Using cluster analysis and content to classify company strategies, they came to the conclusion that companies that follow a differentiation strategy use higher pay-as-you-go (PLC) ratios than companies that pursue cost leadership strategies. In addition, the results show that the heterogeneity between business strategy and reward structure has a negative effect on the performance of the company.

Patan et al. (2008) conducted a study on the size of the board, the independence of the board and the performance of Thai companies. This study, which focused on the period 1999-2003, showed that there is a meaningful and negative relationship between the size of the board of directors of Thai companies and their functions. In addition, there is a positive and significant relationship between the level of independence of the members of the board of directors of the companies and the performance of the companies. 
Batula (2008) examined the relationship between the Board of Directors' characteristics and the performance of companies admitted to the New Zealand Stock Exchange using information from 207 companies during the years 2004-2007, when financial information was available. The findings of this research show that among the different characteristics of the board of directors, only the rate of return on assets and the proportion of ownership has a positive and significant relation with the firm's performance, members of the board of directors have a negative and significant relationship with the firm's performance. We also find that there was no significant relationship between the number of Ph.D. holders and the company's performance. Chehen et al. (2005) investigated the relationship between the concentration of ownership and corporate performance and the dividend policy in Hong Kong Stock Exchanges In this study, the relationship between the concentration of family ownership and the dividend payment of 412 companies admitted to the Hank Kong Stock Exchange during the period 1998-1995 was tested experimentally. They found that there is little relation between family ownership and dividend policy. More precisely, only small companies had a significant negative relationship between paying dividends and family ownership to $10 \%$ of the company's shares and a positive relation between ownership and ownership of between $10 \%$ and $35 \%$.

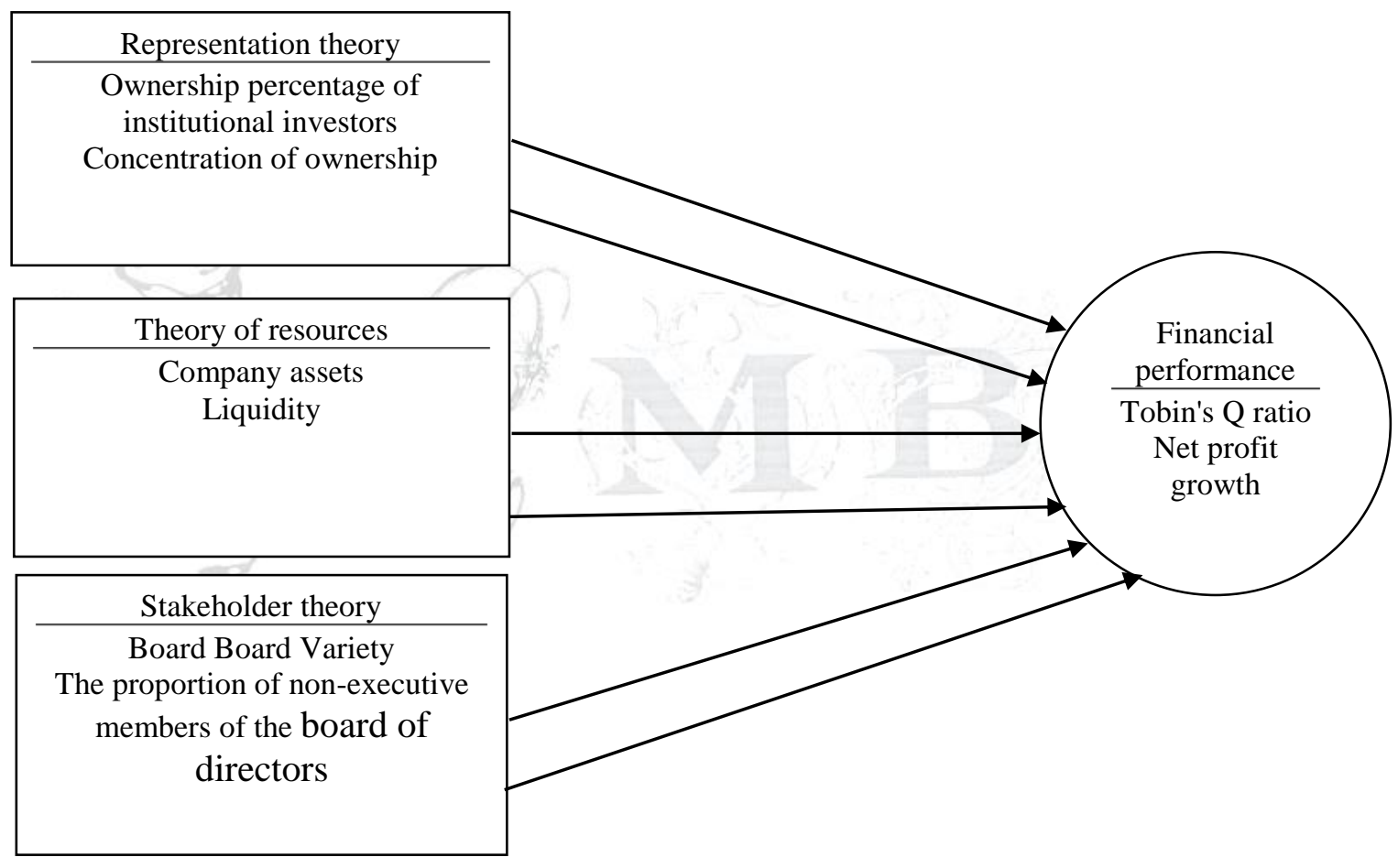

(Figure 1: Conceptual Model of Research (Source: Ajaxi, 2017

In this study, in order to measure the hypotheses explained in the first chapter, according to this conceptual model, the following regression equations are used:

$$
\begin{gathered}
\text { Qtobin }_{i t}=c+\alpha_{0} I O_{i t}+\alpha_{1} O C_{i t}+\alpha_{2} L_{I Q_{i t}}+\alpha_{3} \text { Asset }_{i t}+\alpha_{4} B S D_{i t}+\alpha_{5} \text { NonEM }_{i t}+\varepsilon_{i t} \\
\text { NetIncom Growth }_{i t}=c+\alpha_{0} I O_{i t}+\alpha_{1} O C_{i t}+\alpha_{2} L_{I} Q_{i t}+\alpha_{3} \text { Asset }_{i t}+\alpha_{4} \text { BSD }_{i t}+\alpha_{5} \text { NonEM }_{i t}+\varepsilon_{i t}
\end{gathered}
$$

In these equations: 
Tobin's Q ratio: Indicator of Tobin's Q ratio Bin for measuring the financial performance of company $\mathrm{i}$ in year t.

Net In com Growth it: Net Income Growth Indicator for measuring the company's financial performance i in year $\mathrm{t}$

IO it: Ownership percentage of corporate investors in year $\mathrm{t}$

OC it: Ownership Focus $\mathrm{i}$ in year $\mathrm{t}$

LIQ it: Liquidity of company $i$ in year $t$

Asset it: Company's assets in year $\mathrm{t}$

BSD it: Variation of Board of Directors of $i$ in year $t$

Non EM it: The proportion of non-executive members of the board of directors of $i$ in year $t$

C: Fixed coefficient of regression equation

as: Parameters or coefficients of the regression equation

$\varepsilon$ : Disrupt the regression equation

\section{Research Variables}

The method for measuring the variables in this study is presented in the table below. The method of measuring variables is based on the ASA (2017) study as well as the research organization of the stock exchange.

\section{Data Analysis Method}

After collecting the data from the statistical population, the next step is to analyze the data to test the hypotheses.

Table 1. How variables are measured

\begin{tabular}{|c|c|c|c|}
\hline $\begin{array}{l}\text { Type of } \\
\text { variable }\end{array}$ & Symbol & Name & Measurement formula \\
\hline Dependent & Tobin's Q ratio & Tobin's Q ratio & $\begin{array}{l}\text { Tobin's Q ratio }=\text { (Valuation Company }+ \\
\text { Total Debt of the Values) } / \text { (Total Assets) }\end{array}$ \\
\hline Dependent & $\begin{array}{l}\text { Net In com } \\
\text { Growth }\end{array}$ & $\begin{array}{l}\text { (Financial Performance } \\
\text { Measurement Indicator) }\end{array}$ & $\begin{array}{l}\mathrm{t} \text { year in net profit of year }=(\mathrm{t} \text { year in net } \\
\text { profit }(\mathrm{t}-1) \text { in net profit) / (net profit) }\end{array}$ \\
\hline Independent & $\mathrm{IO}$ & Net profit growth & $\begin{array}{l}\text { Total ownership interest of different types } \\
\text { of institutional shareholders that are } \\
\text { present in the company. }\end{array}$ \\
\hline Independent & $\mathrm{OC}$ & $\begin{array}{l}\text { (Financial Performance } \\
\text { Measurement Indicator) }\end{array}$ & $\begin{array}{l}\text { Number of holders of shares with } \\
\text { ownership of more than } 5 \% \text { of the total } \\
\text { shares of the company }\end{array}$ \\
\hline Independent & LIQ & $\begin{array}{l}\text { Ownership percentage of } \\
\text { institutional investors }\end{array}$ & $\begin{array}{l}\text { Ani ratio = (current asset-commodity } \\
\text { inventory) / (current debt) }\end{array}$ \\
\hline Independent & Asset & $\begin{array}{l}\text { Concentration of } \\
\text { ownership }\end{array}$ & $\begin{array}{l}\text { The natural logarithm of the total assets of } \\
\text { the company }\end{array}$ \\
\hline Independent & BSD & Liquidity level & $\begin{array}{l}\text { One for companies with } 3 \text { or more } 3 \\
\text { members from the private sector, the } \\
\text { public sector, civil society, legal and public } \\
\text { organizations on the board, and zero for } \\
\text { other companies. }\end{array}$ \\
\hline Independent & Non em & Company assets & $\begin{array}{l}\text { Percentage of non-executive members to } \\
\text { total members of the board of directors }\end{array}$ \\
\hline
\end{tabular}


In this section, due to the large volume of data and the necessity of their processing, for estimating descriptive statistics and parameters of the research model, analysis and statistical inference, Eviews software versions 9 and Excel 2013 have been used. To this end, the Excel software has been used to process, categorize and prepare variables and to enter the Eviews software.

\section{Final Results}

Table 2- Research of research hypotheses

\begin{tabular}{|c|c|c|c|c|c|c|c|}
\hline Hypothesis & \multicolumn{3}{|c|}{ Path } & coefficient & Statistics t & probability & Result \\
\hline $\begin{array}{c}\text { Hypothesis } \\
1-1\end{array}$ & $\begin{array}{l}\text { Ownership } \\
\text { percentage of } \\
\text { institutional } \\
\text { investors } \\
\end{array}$ & $<<<$ & $\begin{array}{l}\text { Tobin's } \\
\text { Q ratio }\end{array}$ & 0.006 & 0.135 & 0.892 & Reject \\
\hline $\begin{array}{c}\text { Hypothesis } \\
1-2\end{array}$ & $\begin{array}{l}\text { Ownership } \\
\text { percentage of } \\
\text { institutional } \\
\text { investors }\end{array}$ & $<<<$ & $\begin{array}{c}\text { Net } \\
\text { profit } \\
\text { growth }\end{array}$ & 0.185 & 2.086 & 0.037 & Confirmation \\
\hline $\begin{array}{c}\text { Hypothesis } \\
2-1\end{array}$ & $\begin{array}{l}\text { Concentration } \\
\text { of ownership }\end{array}$ & $<<<$ & $\begin{array}{l}\text { Tobin's } \\
\text { Q ratio }\end{array}$ & 0.034 & 3.313 & 0.001 & Confirmation \\
\hline $\begin{array}{c}\text { Hypothesis } \\
2-2\end{array}$ & $\begin{array}{l}\text { Concentration } \\
\text { of ownership }\end{array}$ & $<<<$ & $\begin{array}{c}\text { Net } \\
\text { profit } \\
\text { growth }\end{array}$ & 0.390 & 3.481 & 0.000 & Confirmation \\
\hline $\begin{array}{c}\text { Hypothesis } \\
3-1\end{array}$ & Liquidity level & $<<<$ & $\begin{array}{l}\text { Tobin's } \\
\text { Q ratio }\end{array}$ & -.088 & -2.981 & 0.022 & Confirmation \\
\hline $\begin{array}{c}\text { Hypothesis } \\
3-2\end{array}$ & Liquidity level & $<<<$ & $\begin{array}{l}\text { Net } \\
\text { profit } \\
\text { growth }\end{array}$ & 0.007 & 1.100 & 0.721 & Reject \\
\hline $\begin{array}{c}\text { Hypothesis } \\
4-1\end{array}$ & $\begin{array}{c}\text { Company } \\
\text { assets }\end{array}$ & $<<$ & $\begin{array}{l}\text { Tobin's } \\
\text { Q ratio }\end{array}$ & 0.074 & 15.498 & 0.000 & Confirmation \\
\hline $\begin{array}{c}\text { Hypothesis } \\
4-2\end{array}$ & $\begin{array}{l}\text { Company } \\
\text { assets }\end{array}$ & $<<<$ & $\begin{array}{c}\text { Net } \\
\text { profit } \\
\text { growth }\end{array}$ & 0.994 & 3.606 & 0.000 & Confirmation \\
\hline $\begin{array}{c}\text { Hypothesis } \\
5-1\end{array}$ & $\begin{array}{c}\text { Board } \\
\text { diversity }\end{array}$ & $<<<$ & $\begin{array}{l}\text { Tobin's } \\
\text { Q ratio }\end{array}$ & -.0006 & -0.119 & 0.905 & Reject \\
\hline $\begin{array}{c}\text { Hypothesis } \\
5-2\end{array}$ & $\begin{array}{c}\text { Board } \\
\text { diversity }\end{array}$ & $<<<$ & $\begin{array}{c}\text { Net } \\
\text { profit } \\
\text { growth }\end{array}$ & -1.421 & -1.682 & 0.093 & Confirmation \\
\hline $\begin{array}{c}\text { Hypothesis } \\
6-1\end{array}$ & $\begin{array}{c}\text { The proportion } \\
\text { of non- } \\
\text { executive } \\
\text { members of } \\
\text { the board }\end{array}$ & $<<<$ & $\begin{array}{l}\text { Tobin's } \\
\text { Q ratio }\end{array}$ & -0.018 & -3.845 & 0.000 & Confirmation \\
\hline $\begin{array}{c}\text { Hypothesis } \\
6-2\end{array}$ & $\begin{array}{c}\text { The proportion } \\
\text { of non- } \\
\text { executive } \\
\text { members of } \\
\text { the board }\end{array}$ & $<<<$ & $\begin{array}{c}\text { Net } \\
\text { profit } \\
\text { growth }\end{array}$ & 0.052 & 0.205 & 0.837 & Reject \\
\hline
\end{tabular}

Using descriptive statistics such as dispersion indexes as well as distortion indicators of symmetry, the characteristics of each of the variables and their status in the investigated companies were examined. In the 
next step, the unit root test was performed to examine the reliability of the variables using Levine, Lane and Chou tests, and it was determined that the research variables are all valid and their variance and mean are constant over time. Then, the correlation coefficients of the variables were determined using the correlation matrix to exclude irrelevant variables. After these studies, depending on the nature of the research data, which is a combination of time series and cross-sectional data, it is time to choose the best model for estimating regression equations, which is firstly done through the chow test to select between POOL and PANEL data, and if The choice of the panel model, the Hausman test is used to select between fixed effects and random effects. After these tests, the best model was selected and the equations were estimated with their best model, and the coefficients for testing the hypotheses were determined. In the next stage, the fitting of the models was evaluated using the relevant statistics. Finally, the classical assumption was examined and it became clear that none of the assumptions was violated and all of them are in place.

\section{Conclusion}

In this research, the effect of variables on the percentage of ownership of institutional investors and the concentration of ownership in terms of representation theory, total assets and liquidity of the company based on the theory of resources and diversity of board of directors and the ratio of non-executive members of the board of directors on the basis of stakeholder theory on the financial performance of companies admitted to the Tehran Stock Exchange Evaluated. For financial performance, according to theoretical literature, two indicators of the ratio of Kyoto and the growth of net profit of the company were considered. Ownership percentage of institutional investors has a positive and significant effect on net profit growth, but does not have a significant effect on the Tobin's Q ratio. In this regard, Mahmoud Abadi and Zamani (2015) showed that the percentage of ownership of institutional shareholders has a positive effect on the relationship between risk and financial performance, and this relationship is reinforced. The results of KoGani and Koğani (2015) also indicate that there is a significant and direct relationship between institutional ownership and the Tobin's Q ratio, which is consistent with the result of this research.

Ownership concentration has a positive and significant effect on both financial performance indicators. The result of this hypothesis is consistent with the findings of Amini (2012) and Mashayekh and Mahapur (2009). Thomson and Peterson (2000) also found a positive and significant relationship between centralized ownership and economic performance as a dependent variable.

The level of liquidity has a negative and significant effect on the Tobin's Q ratio, and the significant effect of this variable on net profit growth of the company was not observed. In this regard, Ebrahimpour et al. (2015) showed that the relationship between liquidity and profitability in automobile and chemical manufacturing is significant, while it is not meaningful for the pharmaceutical industry. This is also consistent with the findings of Tian et al. (2016), which showed that companies with the ability to generate higher liquidity have less profitability.

The company's assets have a positive and significant effect on both financial performance indicators. In this regard, Asadi and Sadri Nia (2013) in their research showed that the assets of the company in the basic pharmaceutical industry have a significant and positive relationship with the company's performance, which is consistent with the result of this research. The diversity of the board has a negative and significant effect on the growth of net profit of the company and there is no significant effect of this variable on the Tobin's Q ratio. In the context of the diversity of the board, Bhagat and Black (2002) in their study showed that the diversity of the board does not improve the financial performance of the companies.

\section{Acknowledgment}

The authors are obliged to thank all those who contribute to this research. 


\section{Resources}

Abrahampour, Mojtaba, Babangejad, Hamed; and Taliban Blacksmith, Meysam (2016), The Relationship Between Liquidity and Financial Leverage on Profitability of Companies Accepted in Tehran Stock Exchange (Automotive and Parts Manufacturing, Chemical and Pharmaceutical), Management and Accounting Research, No. 26: 80-100.

Asadollahi, Zahra and Seyyed Darb, Afshin (2010). Stakeholder Analysis Methods in Participatory Management of Natural Ecosystems. First National Student Conference on Ecology Protection Management.

Azami, Bahareh, Salek, Hamid (2014), Corporate Governance Review and Leverage Ratios on Improving the Management of Tehran Stock Exchange Companies, International Conference on Modern Orientations in Management, Economics and Accounting, No. 16, p. 23-45.

Astana, Fatemeh, Firouzkhah, Anna (2015), Corporate governance relationship and financial leverage on the values of companies accepted in Tehran Stock Exchange, the first international conference on management, economics, accounting and education.

Jamshidi Naveed, Babak; and Izadi, Mohammad Mahdi (2011), Investigating the Effect of Corporate Governance Principles on Investors' Behavior in Tehran Stock Exchange, Financial Engineering and Management of Securities, No. 6: 25-39.

Hajipour, Bahman and Momeni, Mostafa (2009). Recognition of Source-Based Approach to Organizational Resources and Sustainable Competitive Advantage Case Study: Saran Manufacturing Company. Management Thought, Vol. 3, No. 1, p. 77-102.

Haji, z. And moral, HI (2012). Investigating the Factors Affecting the Company's Debt Maturity Structure: An Empirical Test for Representation Theory and Leverage Theory. Quarterly Journal of Empirical Financial Accounting Studies, 33: 167-147.

Sensitive One, Yahya; Poetry, Saber; and Seyyed Hossein Khosrownejad (2008). The relationship between corporate governance mechanisms, debt ratios and company size with profit management. Accounting Studies, No. 24, p. 79-115.

Khodamipour, Hossein, Ansari, Reza and Namazian, Ali (2009). Investigating the effect of corporate asset revaluation on disclosure of assets and income tax on companies. Tax Law Research, No. 7, p. 101119.

Peasant, Mohammad Reza and Makhmalbaf, Ahmad (2015). Brief overview of resource-based approach. Management and Accounting Research, No. 27, p. 59-68.

Rahimian, Nizam al-Din, Ghaderi, Bahman and Rasouli, Peyman (2015). Capital structure and representation theory: empirical evidence from Tehran Stock Exchange. Accounting Research, Volume 6, Issue 3, p. 41-66.

Praise, Mohammad Hassan (2002). Comparison of the predictive power of net profit and operating profit. Journal of Social Sciences and Human Sciences University of Shiraz, Volume 19, Issue 2, p. 113-124.

Praiseh, Mohammad Hosein, Ebrahimi, Shahla (2013), Investigating the Effect of Ownership Focus on the Payment Policy of Dividends of Companies Accepted in the Stock Exchange, Journal of Financial Accounting Research, Year 6, Number 2, 74-61.

Shaykhonad, Reza (2009). Theoretical Basics of Accounting and Financial Reporting. Tehran, Audit Organization; fourth printing.

Abbasi, Majid (2013). Investigating the Impact of Board Board Variety on the Performance of Companies Accepted in Tehran Stock Exchange. Master's thesis, Payame Noor University of Mazandaran.

Ghalibbaz Ali, Hasan, and Rezaei, Fatemeh (2007), The Effect of Board Composition on the Performance of Companies Accepted in Tehran Stock Exchange, Financial Research, 23 (9): 33-48.

Kermani, S.M. (2011). The relationship of working capital management, financial leverage and operating leverage with the profitability of car companies in the Tehran Stock Exchange. Payam Noor University, Faculty of Social Sciences and Economics, Behshahr Center, Accounting Department.

Kougani, Arash and Koogani, Mansoureh (2015). Investigating the relationship between controlling shareholders, board structure and financial performance of listed companies in Tehran Stock Exchange. International Management and Accounting Conference. 
Moradi, Mehdi, Saeedi, Mojtaba and Rezai, Hamid Reza (2013). Investigating the Impact of Board Size and Independence on Representative Costs. Empirical Accounting Research, Year 2, Issue 7, p. 35-53.

Namazi, Mohammad, and Agriculture, Ramin (2009). Investigating the Application of the QT Tobin Ratio and Its Comparison with Other Performance Measurement Metrics in the Companies Accepted in Tehran Stock Exchange, Accounting Progress, Volume 1, Issue 1, p. 231-262.

Namazi, Mohammad; and Mousavinejad, Rohallah; (2015), Investigating the Relationship between Intangible Assets and Financial Performance of Companies Accepted in Tehran Stock Exchange, Investment Knowledge, 25 (5): 243-262.

Norouh, Iraj and Zakeri, Hamed (2011). Earn smoothing through sales of company assets. Financial Accounting Research, Volume 3, Issue 2, p. 51-61.

Nikbakht, Mohammad Reza; Seyedi, Aziz; and Hashemolhosseini, Roozbeh (2010), Investigating the Impact of the Board's Characteristics on Company Performance, Accounting Advances, 1 (2): 251270.

Adjasi, M. and Mbo C. (2017). Drivers of organizational performance in State Owned Enterprises. International Journal of Productivity and Performance Management, Vol. 66 Iss 3.

Barney J. (1991), Firm Resource and Sustained Competitive Advantage, Journal of Management, 17(1), pp. 99-120.

Bathula, H. (2008). Board Characteristics and Firm Performance: Evidence from New Zealand; journal of management 2008; 20:172-186.

Chahal, H. and Kumari, A. (2013). Examining talent management using CG as proxy measure: a case study of State Bank of India. Corporate Governance: The international journal of business in society, 13 (2), $198-207$.

Chen, Z., Cheung, Y., Stouraitis, A. and Wong, A. (2005). Ownership Concentration, Firm Performance and Dividend Policy in Hong Kong. Pacific-Basin Finance Journal, Vol 13, Pp 431-449.

Fama, E. F. and Jensen, M. C. (1983). Separation of Ownership and Control. Journal of Law and Economics, 16: 301-325.

Ming, L. (2007). "Corporate Governance, Auditor Choice and Auditor Switch, Evidence from China." A thesis submitted in partial fulfillment of the requirements for the degree of Doctor of Philosophy. Hong Kong Baptist University.

Mullineux, A. (2006). The corporate governance of banks. Journal of Financial Regulation and Compliance, 14 (4), $375-382$.

Mwaura, K (2007) "The Failure of Corporate Governance in State Owned Enterprises and the Need for Restructured Governance in Fully and Partially Privatized Enterprises: The Case of Kenya", Fordham International Law Journal, Vol. 31 No. 1, pp $34-75$.

Narwal, K.P. and Pathneja, S. (2016). Effect of Bank-specific and Governance-specific variables on the productivity and profitability of banks. International Journal of Productivity and Performance Management, Vol. 65 Iss 8.

Raza, K. (2012). “Application of Network Closure Theory towards Firm innovation in Pakistani Telecom Sector” Scholarly Journal of Business Administration. Vol. 2 No.8, pp.170-178.

Salavei, K. (2010)." Quality of Financial Information and Liquidity". Electronic copy available at: http://ssrn.com/abstract.

Sheikh, N. and Wang, Z. (2012). Effects of corporate governance on capital structure: empirical evidence from Pakistan. Corporate Governance: The international journal of business in society, 12(5), 629 641.

Yasheng, C., and Johnny, J. (2014). Business Strategy, Executive Compensation and Firm Performance. Journal Accounting and Finance, Vol. 54, pp. 113-134. 